銅

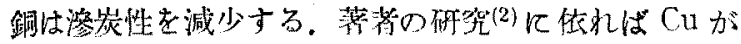

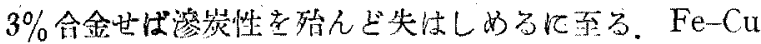

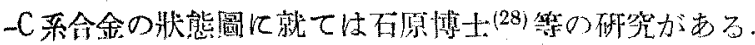

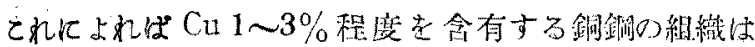

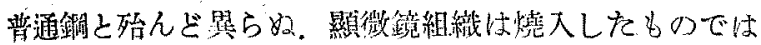

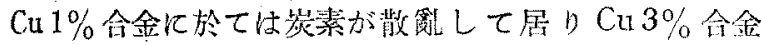

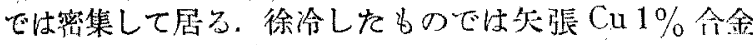
ては波来土が粗くCu 3\% 会金では細かである。

\section{總括}

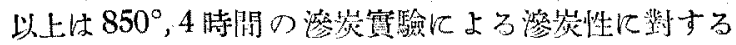
藷元素の影晦を見たものである.マンガン及びモリブデ

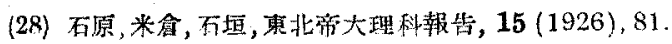

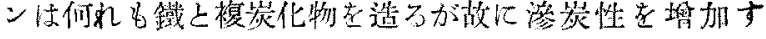
る、クロム、タングステン及びバナデウムは共に崖化物

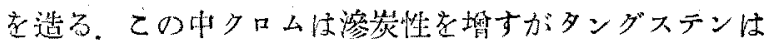

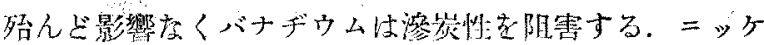

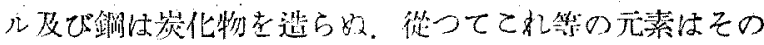
添加量に件し渗岩性が滅少する。アル

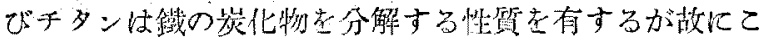

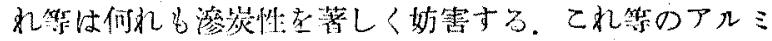

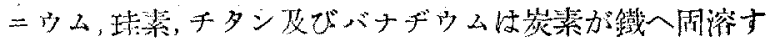
るて上妨彗する。加る元素の会金して居る鐵に渗炭

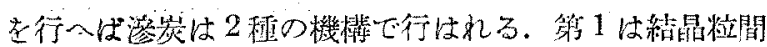

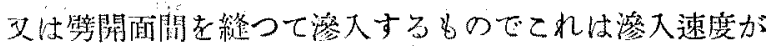

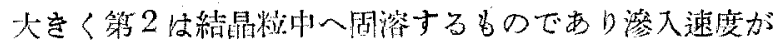
湦々. (未完)

\title{
金屬材料の減衰能(Damping Capacity) (III) (輯錄)
}

\section{其の他の物理的機械的諸性質との關係}

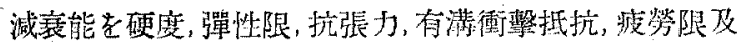
び creep resistance 等と關係附けんと稙な佂てられたが

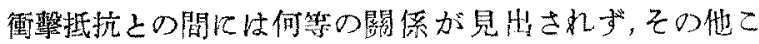
れ等の性質が檑すと大體減衰能は低下する場合が多い㥞 であるといふ以外の一般的閵係仕發見され度い。

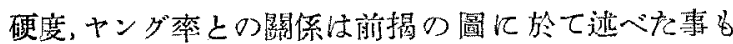

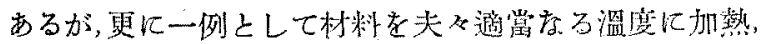

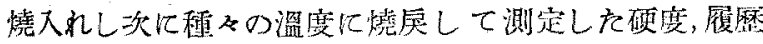
恒數 (引镸照縮應力による)，ャンダ率老第 40 圖(33) に示

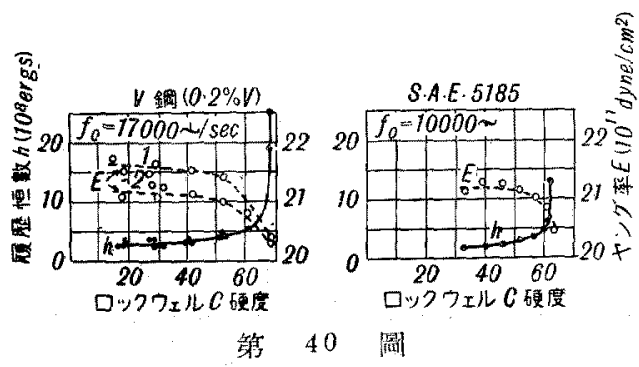

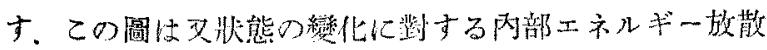

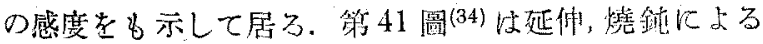

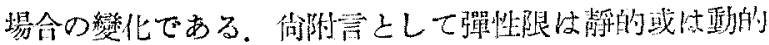

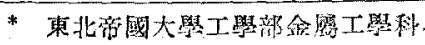

(33) R. L. Wegel, H. Walter, Physics, 6(1935), 141

(34) W. Köster, K.Rosenthal, Z, Metallk, 30(1938), 345.

\section{出口喜 勇 爾*}

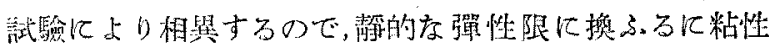

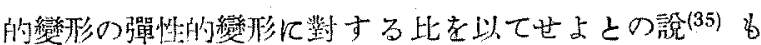

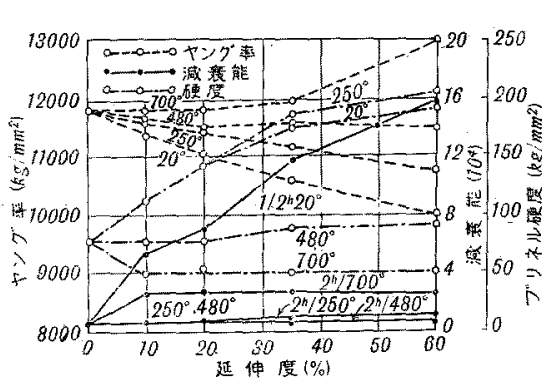

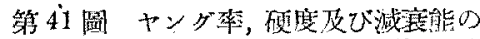

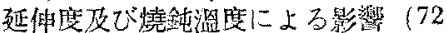

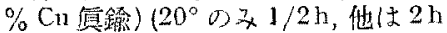
蛙鉣)

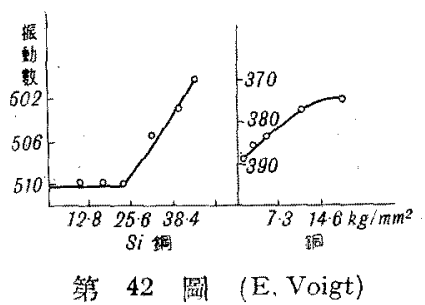

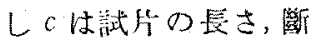
面積及で䠤性率在火 メl, $q, E$ とすれば $c=$ $q . E / l$ と方. この際 の $E$ は颉的の彈性率 で減琵振幅を描くフィ $几$ \& 上 $k$ time mark

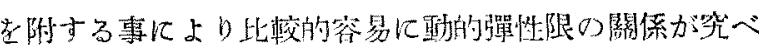
られる。第 42 圆(1) (E. Voigt)に於て朋線が急に上卓し始

(35) E. Siebel, Stahl u. Eisen, 57(1937), 196 , 
せる點が秒的㷵性限にしててれは材料により明膫に表は

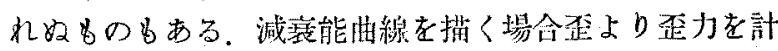

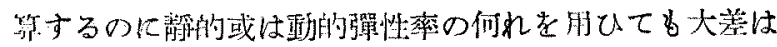
ないと慙はれる(36)が J. Schmidtによると䁘的降伏點を 相觉超過してから疲營限が起る㩐な場合には動的彈性 率が必琴とをる(37)。

抗張力との閵係であるが減衰能泪定試折は大抵機械的

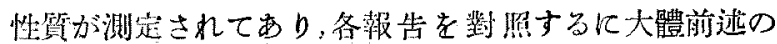
如き䕐論老得る梯で S. F. Dorey ${ }^{(38)}$ によると $3 \% \mathrm{Ni}$ 銅 (扰張力 $47 \mathrm{t} / \mathrm{in}^{2}$ ) \& $\mathrm{Ni}-\mathrm{Cr}$ 銅 (抗張力 $60 \mathrm{t} / \mathrm{in}^{2}$ ) とを土 $14 \mathrm{t} / \mathrm{in}^{2}$ の㨭り歪力で試歌した所前者の減袁能は後者の 約 10 倍であつたと，第 4 表及び第 5 表, 第 43,44 圖(39)

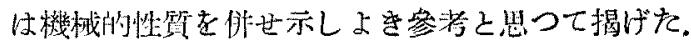

第 5 泰

\begin{tabular}{|c|c|c|c|c|c|c|c|c|c|c|c|}
\hline \multirow{2}{*}{ 林料 } & \multicolumn{8}{|c|}{ 化 學 組 成 $(\%)$} & \multicolumn{3}{|c|}{ 機版的性筫の一部 } \\
\hline & $\mathrm{C}$ & $\mathrm{Si}$ & $\mathrm{Mn}$ & $\mathrm{P}$ & $S$ & $\mathrm{Ni}$ & $\mathrm{Cr}$ & $\mathrm{Cu}$ & $\begin{array}{c}\text { 伸 } \\
(\%)\end{array}$ & 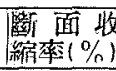 & 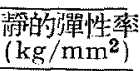 \\
\hline St 37 & $0 \cdot 11$ & $0 \cdot 22$ & $0 \cdot 39$ & $0 \cdot 013$ & 0.029 & - & - & 0.16 & $32 \cdot 6$ & $70 \cdot 2$ & $2 \cdot 11 \times 10^{4}$ \\
\hline St $\quad 52$ & $0 \cdot 14$ & 042 & $1 \cdot 38$ & 0.034 & 0.022 & - & - & $0 \cdot 48$ & $25 \cdot 1$ & $69 \cdot 3$ & $2 \cdot 13$ \\
\hline 條鈃 & 0.44 & 0.28 & $1 \cdot 67$ & 0.028 & 0.031 & - & - & 0.15 & $14 \cdot 6$ & 58.5 & $2 \cdot 14$ \\
\hline $\mathrm{C}$ 鈯 ( $\left(\begin{array}{ll}\mathrm{D} & 6\end{array}\right)$ & 0.64 & 0.11 & $0 \cdot 75$ & 0.020 & 0.052 & - & - & $0 \cdot 10$ & $15 \cdot 1$ & $37 \cdot 7$ & $2 \cdot 11$ \\
\hline 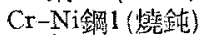 & $0 \cdot 13$ & 0.31 & $0 \cdot 72$ & 0.013 & 0.032 & $4 \cdot 22$ & 0.96 & - & $18 \cdot 2$ & $64 \cdot 2$ & $2 \cdot 06$ \\
\hline ２（調䟭） & $0 \cdot 30$ & $0 \cdot 24$ & 0.49 & $0 \cdot 020$ & 0.027 & $3 \cdot 50$ & $0 \cdot 77$ & - & 14.7 & $66 \cdot 3$ & 2.08 \\
\hline $3(\because)$ & 0.29 & 0.20 & 0.69 & 0.025 & 0.036 & $2 \cdot 93$ & 0.94 & - & $16 \cdot 2$ & $65 \cdot 0$ & $2 \cdot 10$ \\
\hline
\end{tabular}

で闾體粘性に關聯して將氷の閧沉なる研究を留する。 木谷博士が繰返㹉り試醶機により加へる一定 torque を順次變化させて試驗(40)されたものでは周知の如く破

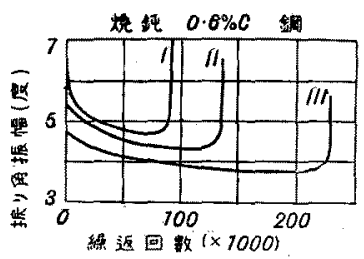

I $\pm 53 \cdot 8 \mathrm{cmkg} \mathrm{III} \mathrm{"} 50 \cdot 0 "$ II " $51 \cdot 9$ "

第 45 圖 始さ．てれは痏勞期の始まりで最後に破壤する。第 46 圆

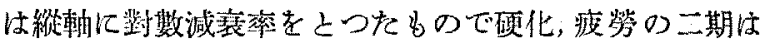

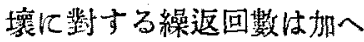
る torque の燴加と共藷 しく減ずる(第 45 圆)。又乙 の結果によると繰返回數の 或る籍圍迄は振幅 (角)の明 かなる減少を東すがこれは 試片の機栈的硬化の镸で極 小值を渦ぐると再び增加し

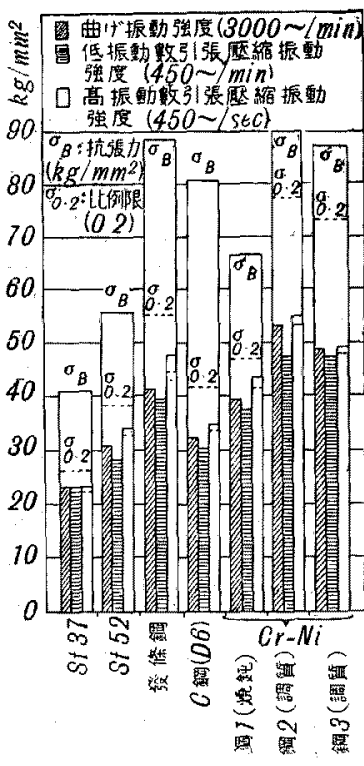

第 43 亩

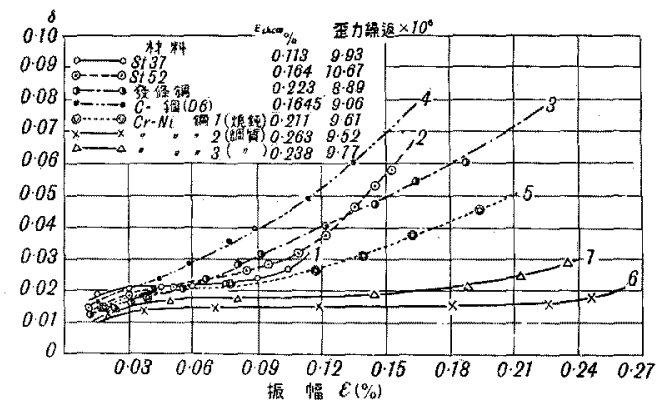

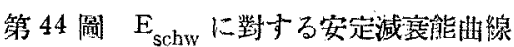
加字子 3 torque 等 しくした繰遮曲線 とよく一致する。

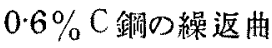
線に於ては振幅の減 少著しくこれは各結 晶粒が相續いて硬化 し局部的の疲管なく 一様なる硬化を過ぐ

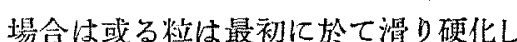
或る繰返回數の後では殘硢の粒の硬化 に先立つて疫營狀態に達する粒もある 事が分る，とにかく繰返肿線の極小值 が結昆粒疲勞の始りを示すと云へ上 ろ.

前にb述べた如く歪力繰返速度と歪 力とが試版の溫度を上㫣せしむるに充 分ならば歪繰返速度之共に溫度が䒜

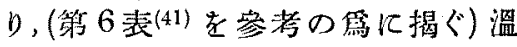

\section{疲勞耐久限, notch sensitivity}

材料の減珵性之疲勞試驗, notch sensitivity或估creep との關係に到つては最も重 要なる關係でありこ〉に項 を改めて述べる。㑑くの試驗村料几つき疲管耐久限等が

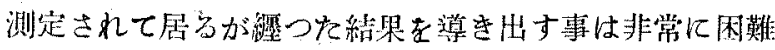

(36) F. Bacon, J. Iron \& Steel Inst, 135 (1937I), 451. (Reply to Discussion)

(37) J. Schmidt, Mitt. Wöhler Inst, Baunschweig, (1931), Heft. 9.

(38) Discussion pages of (2)

(39) F. Körber, M. Hempel, Mitt.K-W-I Eisenforsch., 18 (1936), 15
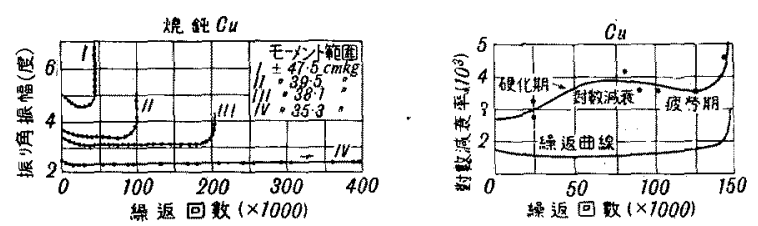

第 46 圖 モーメント $\pm 21 \mathrm{cmkg}$

度が景ると減襄能は高くなつて更に多くの熱量を發生す

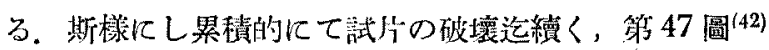

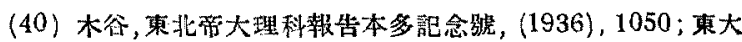
工學部紀要 19 (1930-31),No. 7.

(41) E. Becker, O. Föppl, Forschungsarbeiten a. d. Gebiete d. Ingenieurwes., (1928), Heft 304.

(42) P. Ludwik, R. Scheu, Z. V. D. I., 76-2(1932), 683. O, Föppl, ditto, 1129. (Zuschrift u. Entgegnung) 
第 $\quad 6$ 表

\begin{tabular}{|c|c|c|c|c|c|c|c|c|c|c|c|c|c|c|c|}
\hline \multirow{2}{*}{ 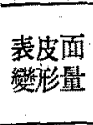 } & \multirow{2}{*}{ 㹉り } & \multirow{2}{*}{$\begin{array}{l}\text { 變形仕案 } \\
\text { 量 } A_{m}\end{array}$} & \multicolumn{2}{|c|}{ 静的䞑驗より } & \multirow{2}{*}{$\frac{1}{n}$} & \multicolumn{3}{|c|}{ 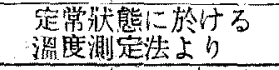 } & \multicolumn{3}{|c|}{ 上舁溫度測定法より } & \multicolumn{3}{|c|}{ 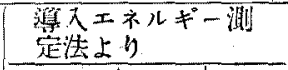 } & \multirow{2}{*}{ 振動綮 } \\
\hline & & & \begin{tabular}{|l|} 
減案能 \\
$9 E$
\end{tabular} & 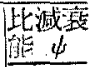 & & $\vartheta$ & $\psi$ & \multirow{2}{*}{$\vartheta / \vartheta_{E}$} & $\vartheta$ & $\psi$ & \multirow{2}{*}{$\vartheta / \vartheta_{E}$} & $\vartheta$ & $\psi$ & \multirow{2}{*}{$\vartheta / \vartheta E$} & \\
\hline$\gamma_{0}$ & $\begin{array}{c}T_{0} \mathrm{~kg} / \\
\mathrm{mm}\end{array}$ & $\mathrm{cmkg/3}$ & $\begin{array}{c}\mathrm{cmkg} / \\
\mathrm{cm}^{3} \sim\end{array}$ & $\%$ & $/ \min$ & $\begin{array}{c}\mathrm{cmkg} / \\
\mathrm{cm}^{3} \sim\end{array}$ & $\%$ & & $\begin{array}{c}\mathrm{cmkg} / \\
\mathrm{cm}^{3} \sim\end{array}$ & $\%$ & & $\begin{array}{c}\mathrm{cmkg} / \\
\mathrm{cm}^{3}\end{array}$ & $\%$ & & $n$ \\
\hline \multirow{7}{*}{0.00160} & \multirow{7}{*}{$13 \cdot 1$} & \multirow{7}{*}{0.525} & \multirow{7}{*}{0.012} & \multirow{7}{*}{23} & 150 & 00115 & $2 \cdot 19$ & 0.96 & 0.016 & $3 \cdot 05$ & $1 \cdot 33$ & 0.0135 & $2 \cdot 57$ & $1 \cdot 12$ & 150 \\
\hline & & & & & 300 & 0.0125 & $2 \cdot 38$ & 1.04 & 0.016 & 3.05 & $1 \cdot 33$ & 0.0145 & $2 \cdot 76$ & $1 \cdot 21$ & 300 \\
\hline & & & & & 600 & 0.0135 & $2 \cdot 57$ & $1 \cdot 12$ & 0.016 & $3 \cdot 05$ & 1.33 & 0.016 & 3.05 & $1 \cdot 33$ & 600 \\
\hline & & & & & 1200 & 0.0110 & $2 \cdot 10$ & 0.92 & 0.016 & 3.05 & 1.33 & 0.015 & $2 \cdot 86$ & $1 \cdot 25$ & 1200 \\
\hline & & & & & 2400 & 0.0105 & $2 \cdot 00$ & 0.88 & 0.016 & 3.05 & $1 \cdot 33$ & 0.014 & $2 \cdot 67$ & $1 \cdot 17$ & 2400 \\
\hline & & & & & 150 & 0.044 & $3 \cdot 73$ & 0.98 & 0.055 & $4 \cdot 66$ & 1.22 & 0.050 & $4 \cdot 23$ & $1 \cdot 11$ & 150 \\
\hline & & & & & 300 & 0.048 & 4.07 & $1 \cdot 07$ & 0.055 & 4.66 & $1 \cdot 22$ & 0.055 & $4 \cdot 66$ & 1.22 & 300 \\
\hline \multirow[t]{3}{*}{0.00240} & \multirow[t]{3}{*}{$19 \cdot 6$} & \multirow[t]{3}{*}{$1 \cdot 180$} & \multirow[t]{3}{*}{0.045} & \multirow[t]{3}{*}{$3 \cdot 8$} & 600 & 0.0455 & 385 & 1.01 & 0.055 & $4 \cdot 66$ & 1.22 & 0.060 & 5.08 & 1.33 & 600 \\
\hline & & & & & 1200 & 0.040 & $3 \cdot 39$ & 0.89 & 0.0555 & 4.70 & 1.23 & 0.057 & $4 \cdot 83$ & $1 \cdot 27$ & 1200 \\
\hline & & & & & 2400 & 0.046 & 390 & 1.02 & 0.0555 & $4 \cdot 70$ & 1.23 & 0.053 & $4 \cdot 50$ & $1 \cdot 18$ & 2400 \\
\hline
\end{tabular}

備考 $0.52 \% \mathrm{C}, 1.32 \% \mathrm{Mn}, 0.22 \% \mathrm{Si}, 0.029 \% \mathrm{P}, 0.015 \% \mathrm{~S}$,

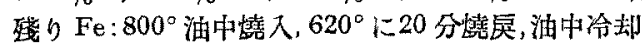

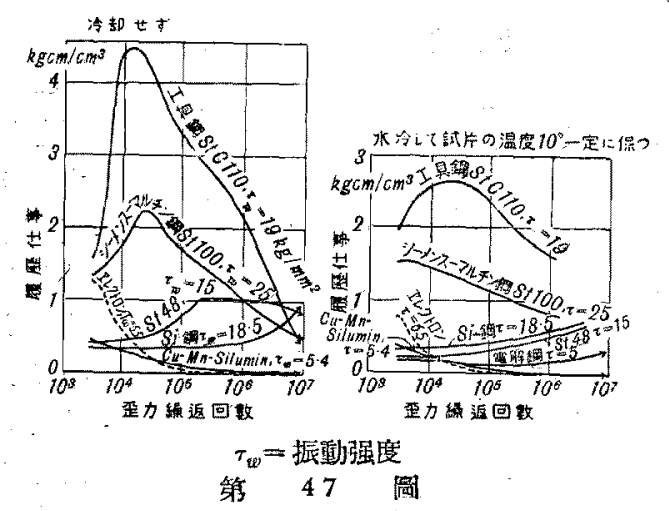

は試片の溫度を一方は一定に保ち他方は然らざる場合の 比較を示す. 大體振動数 $100 \sim 2000$ r. p. m. 迄 ${ }^{(36)}$ 或は 200 2500 r.p.m.(43) 迄は減䒾能に䜳する time factor は

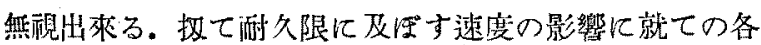

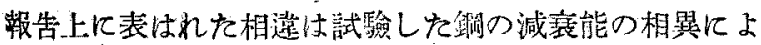
つて說明される，H. F. Moore 及び J. B. Kommers ${ }^{(44)}$ によると 5,000 r. p.m. 迄は耐久限に變化なくG.N. Krause(45)によつては 30,000 r.p.m. 迄は僅かたが上㑊 L G. F. Jenkin 及び G.D.Lehmann(46) は反龂に鍓によ り又その攀處理によるが每分歪力繰返 10,000 20,000 回の間で酎久限が最大になると報告する. Brophy 等の 實驗(23)では限られた數の䞒に就てがはあるが $2,000 〜$ 20,000 r. p. m. で䁈驗して第 7 表に示す如くJenkin 等

(43) E. Bankwitz, Forsch. a. d. Gebiete d. Ingenieurwes., 4(1933), 47. Mitt. Wöhler Inst. Braunschweig, (1932), Heft11.

(44) H. F. Moore, J. B. Kommers, "Fatigue of Metals", Mc Graw-Hill Book Co., Inc., New York City (1927).

(45) G. N. Krause, Proc. Amer. Soc. Test. Materials, 34 (1934), 156.

(46) G. F. Jenkin, G. D. Lehmann, Proc. Roy. Soc, 125 $(1929-\mathrm{A}), 83$.

$$
A_{m}=\frac{1}{2} \int_{\gamma_{0}=0,}^{\gamma_{0}=\gamma_{0} \max } \tau_{0} d \gamma_{0}, \quad \vartheta=\frac{1}{2} \int_{-\gamma_{\max }}^{+\gamma_{\max }} \tau_{0} d \Delta \gamma_{0}, \quad \psi=\vartheta / A_{m}
$$

第 7 琵

\begin{tabular}{|c|c|c|c|c|}
\hline \multirow[b]{2}{*}{ 銊 } & \multicolumn{2}{|c|}{ 耐我限 $1 \mathrm{~b} / \mathrm{in}^{2}$} & \multirow{2}{*}{$\mid \begin{array}{l}20,000 \text { r.p. } \\
\text { m. l 於 } \\
\text { 得失 } \%\end{array}$} & \multirow[b]{2}{*}{$\begin{array}{c}\text { \% } \\
\%\end{array}$} \\
\hline & $\begin{array}{r}2,000 \\
\text { r.p. m. }\end{array}$ & $\begin{array}{l}20,000 \\
\text { r.p. m. }\end{array}$ & & \\
\hline 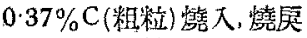 & 45,500 & 41,500 & -8.8 & 8 \\
\hline $0.36 \% \mathrm{C}($ 微䊉 $) "$. & 42,500 & 42,500 & 0 & 5 \\
\hline 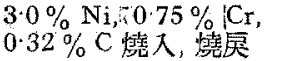 & & & & \\
\hline 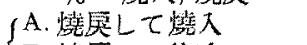 & 66,700 & 76,000 & +13.9 & 3 \\
\hline B. 燢戻して徐冷 & 63,000 & 72,000 & $+14 \cdot 2$ & $2 \cdot 5$ \\
\hline
\end{tabular}

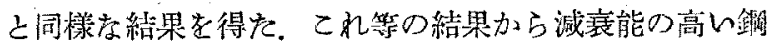

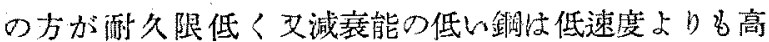

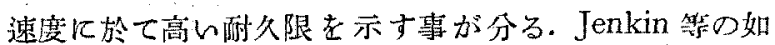
く耐久限が最大值に度るととがあるとすると大骾の狀沉

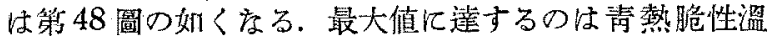

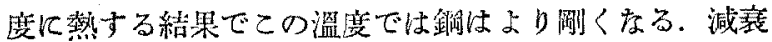

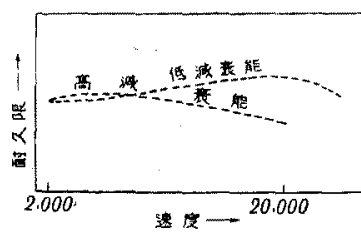

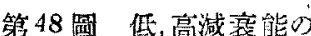
鍓に對し繰返速度によ る耐久限の大腈の變化 宗す

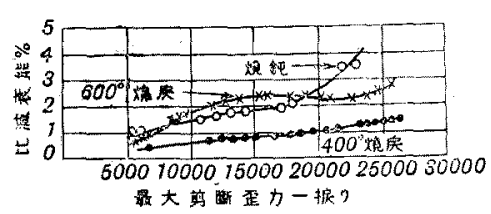

第 49 圆 $3.5 \% \mathrm{Ni}, 0.65 \% \mathrm{C}$ 䥡の減定能

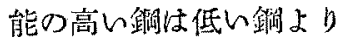
もこの淄度に早く達す る.次に第50圊に見名

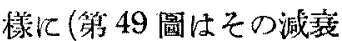
能明線) 然潘試今に邀す る酎久限は唯處理による 抗張力の變化之同じ位儿 變つて㳖はれて居るが有 清試扎の場合には抗張力

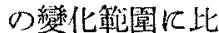
し警くべき狹い 範囯に變化して 居子。然し何等 の規則性は認好 5礼标的。

繰返据り耐久

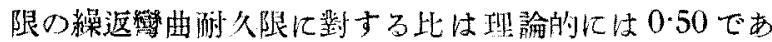


るが實驗によると $0.44 〜 0.71$ の間に變化して本均 0.55 を得(44) (然しこの比の测定值は多數する). 減衰值は歪力 によつて連續的に變る故に或る一定の歪力をとつて比較

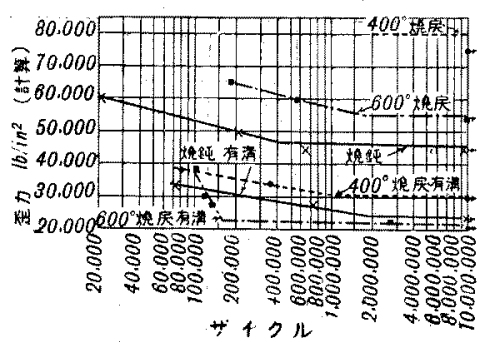

第 50 渔 第 49 置と同じ試片の 激久曲線
する必要がありそ れには

(1) 㿢通の有清 耐久限に對雇する 剪斷歪力に於ける 減襄能をとるも のでてれ歪力 集中因子 (Stress concentration factor $=$ (然澲耐久

限/有满耐久限) 亿對して圖示する.

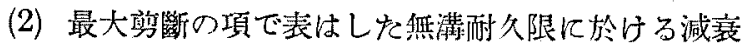
值をとる。

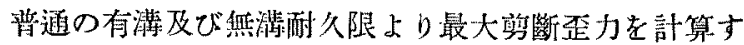

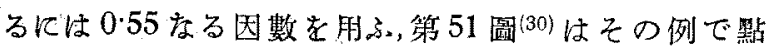

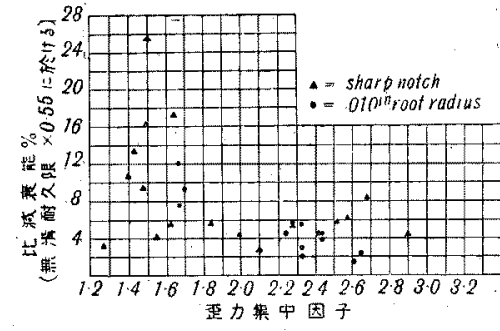
が相當散在して 居るのは 0.55 なる因數老使つ え絾もあら5。

圆よりしててれ 以下では危險， 以上では相當保

護する結果とな
第 51 圆 A. 無幥测久限に對㗹せ

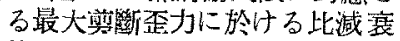
能と notch sensitivity との關係

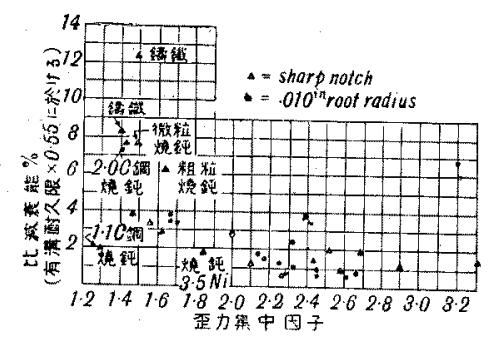

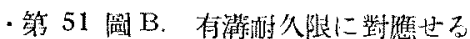
最大署率歪力に於ける比減衰能と

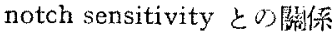
る限帠減票能が

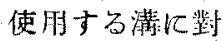
して存在する㭼 に見える.大體 減衰能低 々程 notch sensitive である。これは

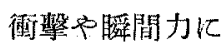
關し低減衰能材 料は頜々角や割 れ目，表面泟，断 酘皘の遙激なる 變化によつて希

力が局部的に集中することが多いといふ。事で, notch sensitivityは組織によつて必影響され又速度により㙕

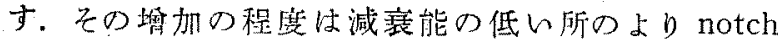
sensitive 灰材料程大きい(弱 8 表)(23).

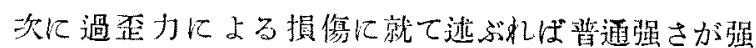

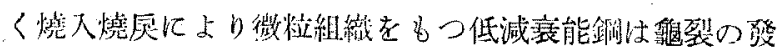
生に對する抵抗は大きいが一度發生するとその notch

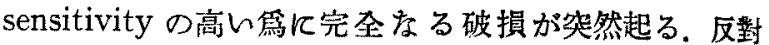

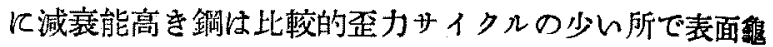

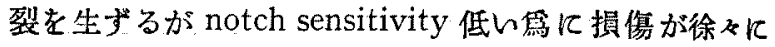

\begin{tabular}{|c|c|c|c|}
\hline \multirow[b]{2}{*}{ 減㝙能 } & \multicolumn{2}{|c|}{ 歪万集中因子 } & \multirow{2}{*}{ 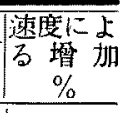 } \\
\hline & $\begin{array}{r}2,000 \\
\text { r.p.m. }\end{array}$ & $\begin{array}{l}20,000 \\
\text { r.p.m. }\end{array}$ & \\
\hline 富 & 1.64 & 1.70 & 36 \\
\hline 中 & 268 & 3.53 & $31 \cdot 5$ \\
\hline 低 & $3 \cdot 32$ & $5 \cdot 54$ & 64 \\
\hline
\end{tabular}

進行する. 第 52,53 圖(30) 几於て撶張性は 實際問題として A, B 殆に゙差異を示さねが A はBょり匴清耐久 限高く過歪力にて上 り賣傷され難い。然し

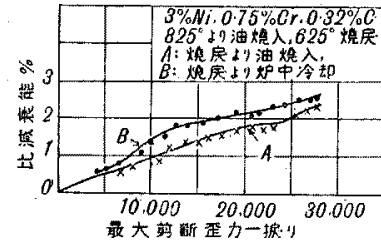

- 第 52 圖 $\mathrm{Ni}-\mathrm{Cr}$ 銈の比減 垶能曲線

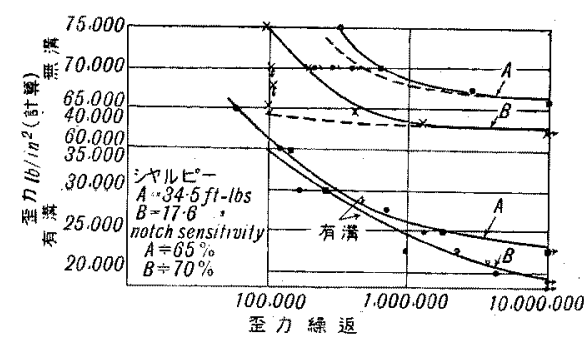

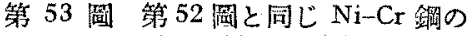
酎久曲線

A：燒居上り燒人

B：蹺戻上り徐冷 n. 乍ら衝骠試驗の場合の 如く高歪力が突然加人 られた際には疲營に於 ける notch effect の抵 抗に粗粒組織の鎦が優 つて居る事は示されな

creep $^{(23)}$ 自由振動 する棒の振 幅の連櫝的 滅至怗性 的變形の結 果である。 粘性は又一 定荷重の下 の棒の連續 的延伸保

つて示される故に同一溫度に於ける減㺯能試驗と creep test との間の少く共定性的の關係は期待し得. $550^{\circ}$ に

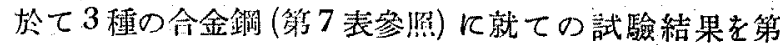
54, 55 圖に示す。結晶粒の範圍を增す临に異つた溫度に

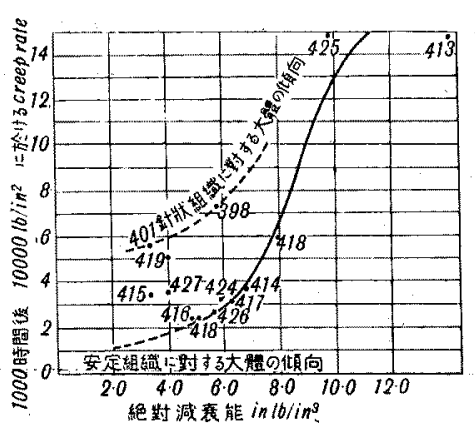

第 54 圖 做南能と creep rate との關係
燒喓しその溫度より

爐中徐冷した故に冷 却速度は近似的化 一である。非常に結 晶粒の大きな試片は 不安定の針彇組織党 度して居る。乙れ等 の曲線より若し減裹 能及び creepが粘性 で测られるならば期 待に反せず減哀能が 減少するとcreep rate 及び粘性的變形の減少する事が 分方.

材料の缺陷 
材料の缺陷は第 56 圆(25) の如く減㜔能を增大する故に てれを利朋して材料の钢陷及びその位置の決定に凟す 3.

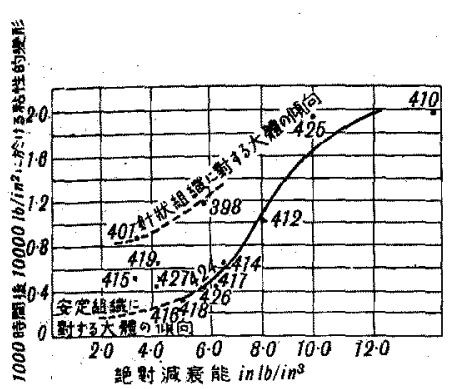

第 55 圆 隇蒉能々粘性的變形 との關係

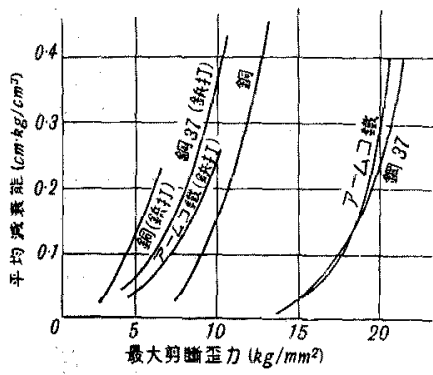

第 57 解 る(b)時の隇琴性

鋯打及び莶接 材料を悇打して継案 合はせる時は熔接する

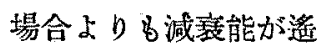
によつて示される. 從 つて浩船等で鋲打を熔 接に置き擐一ると減害 能の低下を來し振動に よる疲嫈破損の危險が 垿す事となる故に特に

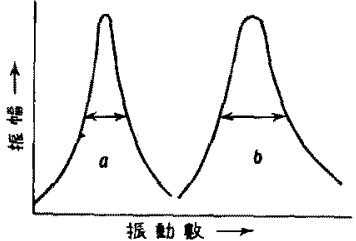

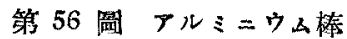
の舆㗞 (a) 及び裂け目あ 亿大なる事は第 57 圆(2)

減衰能の大なる材料を選擇する必要がある。

\section{Discussion 並びに理論的} 諸問題人の一算

凡そ材料試驗に限らず新因子が投ぜらる」時は必要以

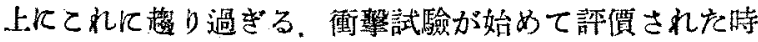

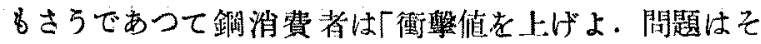
れだ」云つた，減衰能の場合にもその傾问がある。抑 斯る性質は相當以前加ら知られて居たが Föppl が減

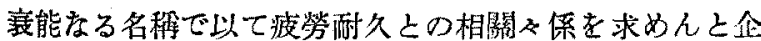
てかから益ね有名になつたもので以前は減衰能が疲勞破 提の第一の指示であつて各材料は一定量のエネルギーし か放散する事が出來ず，この一定量のエネルギーが盖さ れた時に波勞破提が起るとの公理が受け人れられんとす るにさ人到つた事があるが、嘪驗結果は悉くこれを覆一 し減㐮能は差迫つた疲營破損の指示でもなければ特間の 經過之共に消盡されるbのでもない，疲勞長期試驗に撸

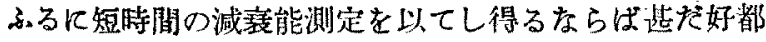
合であるが, 既逃の如く長期荷重に於ける減襄能變化の つき進九方研究並に減衰能筙㴧の決定が必要である。

一體材料の內部摩摖の临に值達さるべきェネルギーの 一部が其處で消費されてしまる。翋であるがこのエネルギ

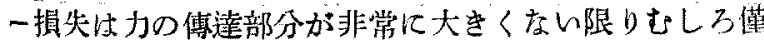
加の量である。今長さ $l の$ piston rod Xは connecting $\operatorname{rod}$ が振幅 $\gamma$ の繰返交互の力を傳ふる時, 力の撌火部分 は $\pi l / \phi \gamma\left(\phi=f^{\prime} / f\right)$ でてれ大抵の場合 $0.1 \sim 1 \%$ 程度 である。(6)

運轉狀態に於ける危險なる振動を除去する孚に機械の 總ての固有振動數が如何なる運轉速度上る異る様に祋計 するとか及制動機として作朋する斬受を使用する方法も ある. 一例として“Chrysler damper”之稱せらるな のをクランクシャフトのフランジによりつけを時のクラ ンクシャフトの振れを第 58 圖(47) 亿示す。乙れ等杜材料

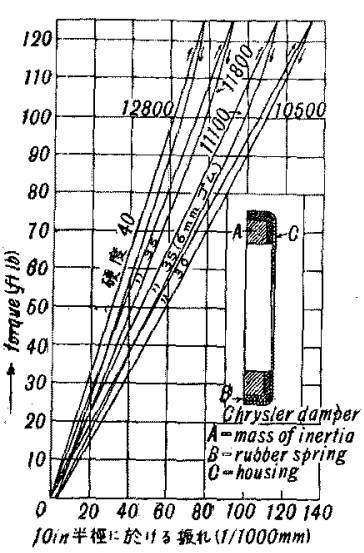

第 58 圖 の不經濟なる使用或は土ネ ルギーの面に大をな損失と か永久性のないてと等で残 ましくはなん。所で A. L. Kimball が趣轉するシフャ トの運動に峳行する減䒾能の 影響索研究(48)した所によ ると自由端によつて蓗重し を趩轉片持梁のシャフト纯 垂直面內には偏倚せずに シャフト材料の減衰能に 比例して側方一の偏倚を示 す。更に減衰能は好ましか らざる旋呬效果を薏起すると、呬轉するシャフトに於ては 高減衰能は好ましからざる旋建效果を起すかも知礼始が 同じ減衰能はクランクシャフト叉は他の自由振動部分の

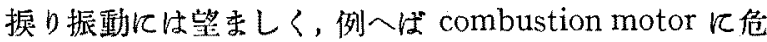
險な又は其鳴衝慗が起つた際クランクシャフトが若し高

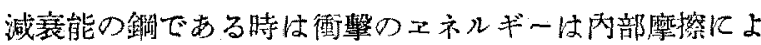
つて消失されて小さ存振動に此められる結果歪力㤝分 疲勞限內にある事しなるが低減衰能の錩では材料の內部

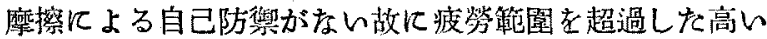
共㕷歪力が更に起り易くなる。. F. Neugebauer ${ }^{(49)}$ によ ると圓筒の援り振動の際 “ResonanzvergröBerung” $V$ （共振に上る振幅の增加割合）は次の如くなる。

$$
V=\frac{2 \pi}{i \gamma_{\mathrm{R}}^{\mathrm{b}}} \frac{1-\alpha^{4}}{1-\alpha^{\mathrm{b}+4}}=\frac{2 \pi}{\psi} \frac{1-\alpha^{4}}{1-\alpha^{\mathrm{b}+4}}
$$

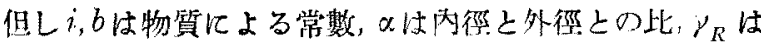

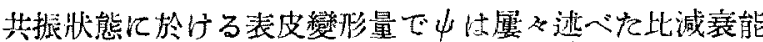
である，その材料の內部的效果のみが共䲧破壤老妨ぐる に絕對充分なりや否やは問題であるが振動を受けて困る 機峨部分の設計者は他の性質に大差をいならば高減衰能

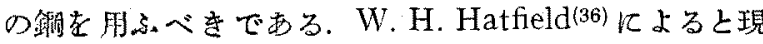
今使用されて居るタービン翼材料の比名成功せる。のは

(47) N. S. Stern, Automobile Eng, 28(1933), 300

(48) A. L. Kimball, General Elect. Rev., 27(1924), 244.

(49) F. Neugebauer, Luftfahrtforsch., 13(1936), 57. 
Föppl 等により登表されを表より見る之但減衰能のもの 郎ち硬化焼戻した $13 \% \mathrm{Cr}$ 銓である，又今日の航空發動

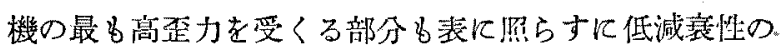
ものより成つて居ると，之に對し F. Bacon の筫驗に上

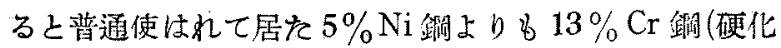

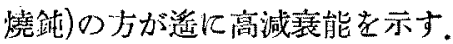

減㐮能之notch sensitivity, 疲營耐久限等之の閶の閶 係の如き全く種々の條件によつて錯綜して居り，例へば 荷重の强さ及び時間, external notch (㙓面疵, 断面の變

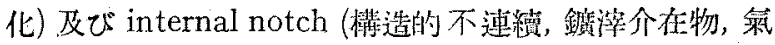

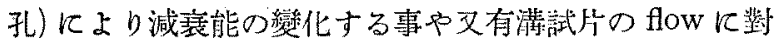
する抵抗等江上つて谷及複雜化され，低減衰能材料は "dynamic toughness"の優れて居る爲に notch sensitive であると云る如き簡單な一䉝的關係は存在しない(50) 怺で決定的索綃論は更沉つき進んだ多くの研究を要す る. S. L. Case(51) 亿よると「燒鈍狀態の锎の減萎能が適 當の處理によつて低下されを時に繰返歪力下に於けるそ

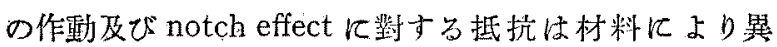
り，微粒組織及び粗粒組織の践はその變化量に相暴を來 すであらら」とたけは云へる. 又氏は「1931 年以來炭萎

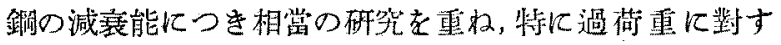

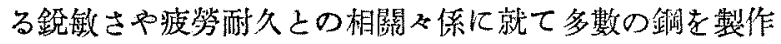
試驗したが，減衰的性質は鼠初自分が考へたよりも滛に 複雜である事が分つた」と述へて居る，前揭Brophyの 疲勞之の關係の如き戠多の吟味要要する所であつて夫ネ の關係在證據附けるべき充分なる䁈驗結果なく，又あり としてる前述の如き理的で餘りに凅ふである。 その最も 䓕をしい例として H. Sonnemann が委託販黄の標準軟 錩の棒につき抗張力及び伸びも同じ故に繰迈し曲げ及び

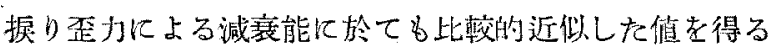
もの之豫想して行つを紹果估第5 59 圖:52)の如く單に明げ

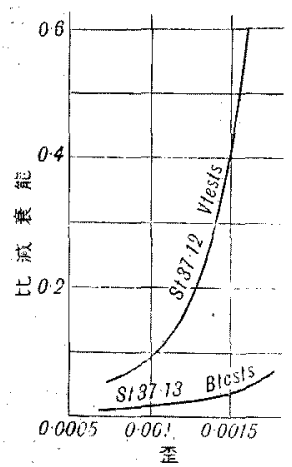

第 59 圆 及び㨭り歪力の故にのみ訾し難 き程つ相違走して絬局颡明は つかをい样である。低つて相閣 ふ係の普逷化のみに夢中になる 前に試騟機械棈造部材の状態と の關係に就て先づ科學的に第鰲 する事が必要である。最後に Föpplがこ狆だけは明らか謨 り疗しとして次の事項索げ た.

(1) 減寒能は是の粘性的部分

(50) P. Ludwick, Z. V. D. I., 25 (1933), 221 ; Congrès de Zurich, 1(1931), 325.

(51) S. L. Case, Discussion pages of (30)

(52) H. Sonnemann, Mitt. Wöh]er Inst. Braunschweig, 1936, Heft 28.

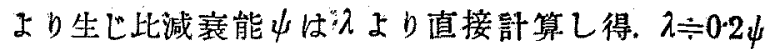
なる關係を提出したのは數年前で多くの科學的報告に引 利されて居るが如何なる賽驗测定も倜々の觀察によって

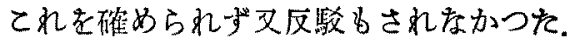

(2) 高歪力教けを純彈性的歪によつて或る一點江甚 だしい歪力集中が起つた際その危險な點に於ける歪力の

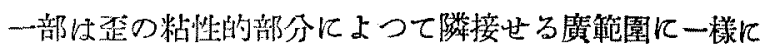
移されるが，最大歪力の點に於ける粘性的降伏が大るる

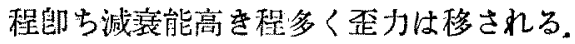

とにかく減衰能と他の諧性質との關係につき互に相反 する實驗紹果多く概略的にで名或る關係法則老導き出す 事は因難之思はれる程であるとは云る。の小抗張力，硬 度低く粗粒組織》場合に高減咅能が得られ易く文過荷重

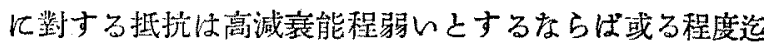

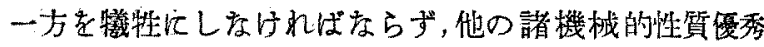
にして然も倘相虽隇衰能高き材料を發見する事が必要で Föppl は低歪力r於て高減衰能の延伸性坽の如き新材料 飞對する稌地すりと暗示老與へて居る.

要するに設計汇祭して減害能を取扱ふてとは實際問題 に於て未炎动年期にある。

減衰能の原因及びその變化に就ては更に廣沉な研究範 圍它提供して居る，材料の形狀，寸法及び振動狀態を一 定とする为尚村質に上つて熱，普等の形で振動系外一逸 散されるェネルギー量從つて減莑能が巽るは流體の場合 の如く各材料が異る粘性或は內部抵抗を持つ䳕と考へら る. 䄳力繰返回數及び繰返歪力の大きされよる減衰能の 變化が異つを村料では全然異つて居ると云ることは，材

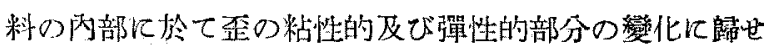
らるべきであつて、減黄能がもはや變化しなくなつた時 始めて材料內部仿於りる斯る變化が起らなくなつてと云

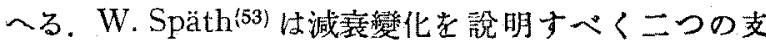
墨間に張られた役條の中央に存する摩擦原素の模型によ り縱及び僙の減衰能 (Längs-und Querdämpfung) なる 概念を導入したが,M. Hempel はての网減変能を分けて 測定し得る如可能性力゙全然ないと云つて居る。減衰能 の變化怡粘性的不均一性の變化すると云方概念中內的歪 力, 結晶の滑り, 空間格子の歪, 又は組蘵の變化となるべ

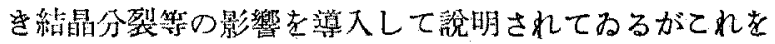
固體の內部抵抗火歸せしむることは最も簡單である、然

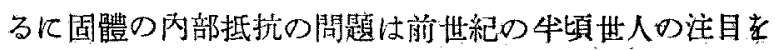
引いてから既に80年を經過せるに拘らず Kelvin, Voigt

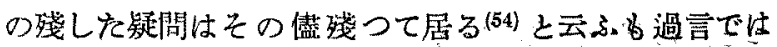
ない。

最初固體の內部摩擦は流體化於ける粘性と全く相似で

(53) W. Späth, Arch.Eisenhüttenwes., 8(1934-35), 405.

(54) 樋口，炧用物理，5(1936), 413. 
西つて，內部摩擦の雼に起る歪分力は歪速度の線狀逐数 として表はし得ると假定された。刎論充分な貝驗的證朋 によづすのではないが此の流體粘性抵抗說は一種の常 識的推諭であつて小振動の場合その真なるてとは承認さ るべきものである。この說は從つて相當廣く且古くより 考へられたものであるがW. Voigt(55)が始めててれを體 系づけ固體の內抵抗の內容を組織的に說明したと云へ上 3. 氏生片持梁の先端に錘を附けたるのを試驗片として 實驗してれ理論的に處理して金屬の固體粘性係數を提 唱した。本多，今野兩氏(56)，五百旗頭，酒井兩氏(57) 等の 本問飞關する研究も又廣く引用されて著名である。本多，

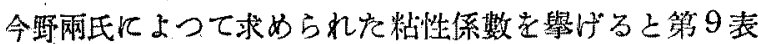

\begin{tabular}{|c|c|c|c|c|c|}
\hline 金 & & 鐲 & & $\begin{array}{l}\text { 本多，今野兩氏 } \\
\left(\times 10^{8}\right)(\text { CGS單位) }\end{array}$ & $\begin{array}{l}\text { 樋口氏 } \\
\left(\times 10^{9}\right)\end{array}$ \\
\hline \multirow{2}{*}{\multicolumn{3}{|c|}{ Al }} & 熙延 & 0.822 & 0.98 \\
\hline & & & 燒 & 1.25 & 1.67 \\
\hline \multirow{2}{*}{\multicolumn{3}{|c|}{$\mathrm{Zn}$}} & & $27 \cdot 4$ & $2 \cdot 90$ \\
\hline & & & 燒 & $9 \cdot 27$ & 5.01 \\
\hline & \multirow{2}{*}{\multicolumn{2}{|c|}{$\stackrel{\mathrm{Ag}}{\prime \prime}$}} & 蹅 打 & $2: 85$ & 1.49 \\
\hline & & & 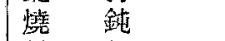 & 224 & $2 \cdot 82$ \\
\hline & \multicolumn{2}{|l|}{$\mathrm{Mg}$} & 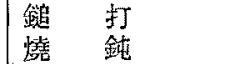 & $\begin{array}{l}1 \cdot 61 \\
0.722\end{array}$ & 0.74 \\
\hline & \multicolumn{2}{|l|}{$\mathrm{Ni}$} & 裖延 & 3.05 & $2 \cdot 11$ \\
\hline 真 & & 鍮 & $\begin{array}{r}\mathrm{Cu} 58.9 \% \\
\mathrm{Zn} 39 \cdot 4 \%\end{array}$ & 1.55 & (燒鉪) $1 \cdot 22$ \\
\hline 炭 & $\begin{array}{l}\text { 素 } \\
", \\
" 1 \\
" 1\end{array}$ & 鋼 & 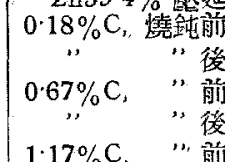 & $\begin{array}{l}4 \cdot 94 \\
268 \\
5.93 \\
4 \cdot 30 \\
7 \cdot 20\end{array}$ & \\
\hline \multicolumn{3}{|c|}{$\underset{, " \text { Duralumin }}{\text {, }}$} & 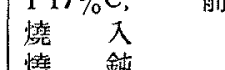 & & $\begin{array}{l}0.68 \\
1.005\end{array}$ \\
\hline & \multirow{2}{*}{\multicolumn{2}{|c|}{$\begin{array}{l}\mathrm{Cd} \\
\mathrm{Sn}\end{array}$}} & 跮延 & & $4 \cdot 01$ \\
\hline & & & , & & $3 \cdot 78$ \\
\hline & 銅 & & $1.36 \% \mathrm{C}$ 爦 鈍 & & $3 \cdot 39$ \\
\hline 歌 & & 鐦 & $0.15 \% \mathrm{C}$ & & $3 \cdot 03$ \\
\hline
\end{tabular}

の如くで，佾樋口氏が强制振動によつて求めた見掛けの

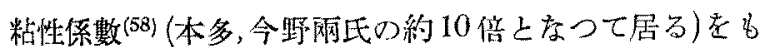

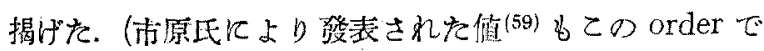
ある.)妹澤博士は棒又は他の固體飞停へられる衝擊の問 題に關聯して固體の粘性飞特别の注意を向け，又有力な る研究を發表された。晋通の慣性棒の属げ层動方程式に 始めて絬性抵抗の頂を導入されたものは懒士である。即

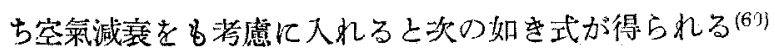
但し $x, y, t$ は座標及び時間, $\dot{\rho}, E, k, \varepsilon, \zeta$ は夫ふ棒の密

(55) W. Voigt, Ann. Phys. 47(1892), 671

(56) 本多，今野，果北帝大理科報告，11 (1922)，435，Phil。 Mag., 43(1921), 115.

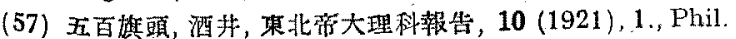
Mag., 43 (1921), 397

（58） 口，東北大工學部報告，10(1931)，506

(59) 市原, 東北大工學部報告, 11(1935)，512

(60) 妹濹，果大航架研究所報告，4(1929), No. 45.

$$
p \frac{\partial^{2} y}{\partial t^{2}}+E k^{2} \frac{\partial^{4} y}{\partial x^{4}}+\varepsilon k^{2} \frac{\partial^{5} y}{\partial i \partial x^{4}}+\zeta \frac{\partial y}{\partial t}=0
$$

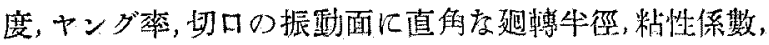

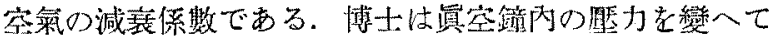

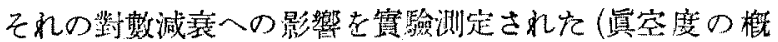
略的影響に就ては E. Voigt(1) 等參原).その一例を第 10 表に掍〈゙(61)。

第 10 表

\begin{tabular}{|c|c|c|c|}
\hline 履 & & $\lambda_{0} \times 10^{3}$ & $F_{0} \times 10^{-7}$ \\
\hline Duralumin & 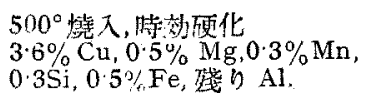 & 1.75 & 080 \\
\hline $\mathrm{Al}$ & 笻延鈑， $99 \cdot 3 \%$ & $2 \cdot 44$ & 0.68 \\
\hline $\mathrm{Cu}$ & $99.9 \%$ & $1 \cdot 90$ & 0.97 \\
\hline 穓鏚 & $" \quad 60 \% \mathrm{Cu}, 40 \% \mathrm{Zn}$ & $2 \cdot 17$ & $1 \cdot 40$ \\
\hline
\end{tabular}

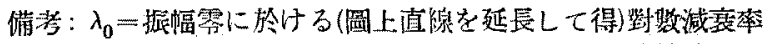
$\varepsilon_{0}=$ 固䁃粘性係数

所で諸家の本問の賽驗結果によると固體の內部抵抗は

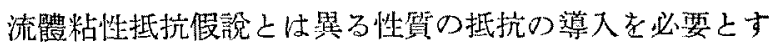
る事が縄論される.S. L. Quimby(62)，A. L. Kimball 及 び D. E. Lovell(63) , O. Föppl(64) 筞は先づ各サイクルに 就てのエネルギー損失は少く其晋通の金屬の彈性限內で

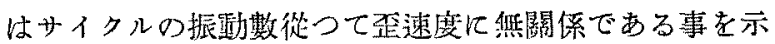
した. Kimball 及び Lovell 结實驗結果から次の如き法 則老歸約した。

$$
F=\boldsymbol{\xi} f_{m}^{2}
$$

但L F は 1 サイタ，單位體積賞りの抵抗損失, $\xi$ は 1

\begin{tabular}{|c|c|c|c|}
\hline 金 & 篛 & & $\begin{array}{c}\xi \times 10^{15} \\
(\mathrm{CGS} \text { 毠位) }\end{array}$ \\
\hline \multirow{6}{*}{ 傎 } & $\mathrm{sn}$ & \multirow{3}{*}{ 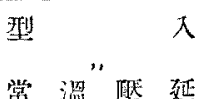 } & \multirow{2}{*}{$\begin{array}{c}402 \\
20.8\end{array}$} \\
\hline & $Z_{n}$ & & \\
\hline & Al & & \multirow{2}{*}{$\begin{array}{l}5 \cdot 7 \\
5 \cdot 6\end{array}$} \\
\hline & 鍮 & 常 溫 㼂 起 & \\
\hline & $\mathrm{Cu}$ & .. & 4.95 \\
\hline & W & & 426 \\
\hline \multicolumn{2}{|c|}{ スウエーデン齫 } & \multirow{2}{*}{ 学泊 } & \multirow{2}{*}{$\begin{array}{l}4 \cdot 16 \\
2 \cdot 67\end{array}$} \\
\hline 粪 & 清 铜 & & \\
\hline \multirow[t]{4}{*}{ 莰 } & 鎆 & \multirow{3}{*}{ 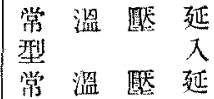 } & $2 \cdot 33$ \\
\hline & Mo & & 1.95 \\
\hline & $\mathrm{Ni}$ & & 1.55 \\
\hline & $\mathrm{Ni}$ 餾 & $35 \%$ 㚅 & $1 \cdot 10$ \\
\hline 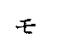 & 亦 & \multirow{2}{*}{ 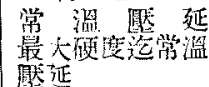 } & $0 \cdot 79$ \\
\hline 燐 & 汪 & & 0.306 \\
\hline
\end{tabular}

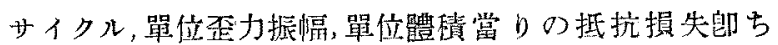
Kimball 及び Lovell ळ订 摧抗 常 數, $f_{m}$ は その時の 歪力サイ クルの振 幅であ 亏. $\xi \varnothing-$ 例老第 11 垗に示す。 及朴谷博 士は炏の如式を提恬さ礼て居る(65)。

(61) 妹澤 東大航究研究所報肯，7 (1932 33)，No. 89

(62) S. L. Quimby, Phys, Rev., 25(1925), 558.

(63) A. L. Kímball, D. E. Lovell, Phys. Rev.; 30 (1927), 948 :

(64) O. Föppl, Z. V. D. I., 70(1926-2), 1291 etc.

(65) 木谷, 果大工學部紀要, $19(1930 / 31)$, No. 1, No. 5 . 


$$
\omega=\gamma \Delta_{m}^{2}
$$

但し $\omega$ は單位體䞍當り粘性變形の完全サイクルによ る放散エネルギー， $A_{m}$ は任意位置化於ける最大歪， $\gamma$

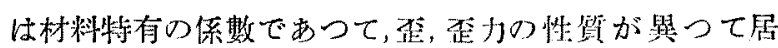
ろが大體 Kimball 說を支持して居るものである。更に S. F. Dorey ${ }^{(68)}$ によつては1サイクル單位體積當りのエ ネルギー $\delta W$ は次》如くなる。

$$
\delta W=A S^{m}
$$

但L $A$ は履歷恒數， $m$ は履歴指數， $S$ は繰返歪力の牛分 り歪力籍園老示す。

扱て上述の各理論實驗には夫れ支持者多多いが向斯く の如き假說及びこれに類似の單独の理論のみで一般減衰

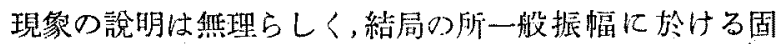
體內部抵抗の分野は（小歪力の筙圍については既述の如 し) 村料の彈性餘效果の減衰現缘への影㗽者含めて今 後の滴切なる實驗結果を持をなければなるまい。乙の解

(66) S. F. Dorey, Proc. Inst. Mech. Eng, 123 (1932), 479.

（67）樋口，東北管大理科啹告，25 (1935-6)，1122；26(1937), 236.

份多少と电參照した諭交は

K. Bennewitz, "Uber elastische Nachwirkung, elastische Hysteresis u. innere Reibung," Phys. Z., 25(1924), 417

O. Föppl, "Die Drehschwingungsmaschine, eine neue Prüfmaschine zur Gütebestimmung von Werkstoffen," Z. V. D. I., 68 (1924), 203.

" ", "Versuche zur Wertung der Baustoffe auf Grund ihrer Dämpfungsfähigkeit," $Z$. angewandte Math. u. Mech., 5(1925), 133.

, ", "Die Drehschwingungsprüfmaschine u. die mit ihr feststellbaren Ergebnisse, " Z. Metalk., $20(1928), 142$

" ", "Bestimmung der Werkstoffdämpfung mittels der Verdrehungsausschwingmaschine, " $Z$. V. D. I., 72 (1928-2), 1293.

" , , "Die Abhängigkeit der Dämpfung von der Verformungsgeschwindigkeit," Arch.Eisenhüttenwes., $4(1930-31), 607$.

P. Lndwik, "Dauerversuche an Werkstoffen", Z. V. D. I., 73-2(1929), 1801.

I\%. Memmler, K. Laute, "Dauerversuche an der Hochfrequenz-Zug-Druck-Maschine(BauartSchenck)", Forschungsarbeiten a. d. Gebiete d. Ingenieurwes., Heft 329, 1930

E. Lehr, "Stoffprüfung," Z. V. D. I., 75-2 (1931), 1401. (Zuschrift von O. Föpplu. Entgegnung von P. Ludwik, Z.V. D. I., '76-1(1932), 345, 346.
園に於ける抵抗が如何なる型のものであるかは今日は不 明である，樋口氏は固體䵇擦の普通の形の固體內抵抗を 導入し ${ }^{(67)}$ 例へ仗水平に橫たはる發保丈は彈性棒より成 る系の一端國定，他端に荷重のある場合は次の如き運動 方程式(但し $\mu$ は周體內部粘性係數)より数學的取扱ひの

$$
\frac{\partial^{2} y}{\partial t^{2}}=\frac{E}{\rho} \frac{\partial^{2} y}{\partial x^{2}}+\frac{\mu}{\rho} \frac{\partial^{3} y}{\partial t \partial x^{2}}
$$

結果に基いて彈性的振勳の減衰に及住す上述の抵抗の影 響例人ば減衰比，對數減害率の減少を研究した。てれるー 般歪力範園の內部抵抗の晦明を目的としたものである。

以上は原んの一例に過ぎずてその他多くの研究家に よつて疲勞の程度を減衰能によつて定戔せんとする等て の紛紏錯雜せる問題の實驗的並に理論的解決が企てられ て居る。前途峻嶮なりとも美事解決されん事を望んでや まない次第である。(完)

G. Parzich, "Die Dämpfungseigenschaften von Nichtmetallen," Forcsh. a. d. Gebiete d. Ingenieurwes., 4(1933), 8.

W. Klein, "Die Messung der Baustoffdämpfung durch Aufnahme der Resonanzkurve," Ing. Arch., 5 (1934), 1.

A. Gemant, W. Jackson, "The Measurement of Internal Friction in some Solid Dielectric Materials", Phil. Mag., 23(1937), 960.

R. K. Bernhard, "Dynamic Test by Means of induced Vibration," Amer. Soc. Test. Materials, 37 (1937), 634 .

G.A.Downsbrough, "The Damping of Torsional Oscillation in Quartz Fibers," Phys. Rev., 51(1937), 877.

F. Förster, H. Breitfeld, "Ein Gerät zur unmittelbaren Dämpfungsanzeige," Z. Metallk., 30(1938), 343.

E. Scheil, W. Thiele, "Änderung von Elastizitätsmodul u. Dämpfung einer $\mathrm{Fe}-\mathrm{Ni}$ Legierung bei der $\gamma-a-U m w a n d l u n g "$, Arch. Eisenhüttenwes., 12(1938/39), 103.

H. Buchner, "Die Elastizitätsgrenze von Stählen bei Dauerbeanspruchung $\mathrm{u}$. ihre Zusammenhang mit der Dauerfestigkeit,Werkstoffdämpfung u. Kerbempfinlichkeit," Forsch.a. d. Gebiete d. Ingenieurwes., 9 (1938), 1

力石(拈)，精密機珹，5(1938)，23.

飯田，“物質の固體粘性火就て”，地震，10 (1938)，100; 151.

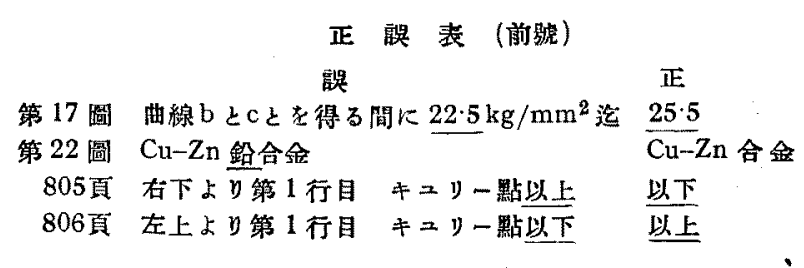

